\title{
Reoquatia
}

Malaysian Tournal of Society and Space

\section{Fisheries practices and fish diversity in Muda and Beris Lakes: a preliminary survey study}

\author{
M. Sharifudin ${ }^{1}$, Zati Sharip ${ }^{1}$ \\ ${ }^{1}$ Lake Research Unit, Water Quality and Environment Research Centre, \\ National Hydraulic Research Institute of Malaysia \\ Correspondence: Zati Sharip (email: zati@nahrim.gov.my)
}

Received: 14 August 2019; Accepted: 19 February 2020; Published: 27 February 2020

\begin{abstract}
Beris and Muda are two artificial lakes that have shifted from lotic to lentic system. Despite both lakes were created for irrigation and source of drinking water, they provide fish habitat for human consumption. This study was carried out to find out the effect of different management approaches on fish in the studied lakes. Muda Lake was utilized for commercial fisheries; this lake hosts around 50 active fishermen compared to Beris that has all part-time fishermen. The catch and the existence of fish landing centre makes the Muda a successful lake for commercial fisheries. In contrast, Beris Lake has also developed its fisheries activity, but concentrates more on the recreational aspect which is well developed at this lake. The existence of many chalets providing boats for sport fishing makes Beris Lake more successful than Muda Lake. The study found a contrasting impact of introducing different alien species where may cause benefit at Muda Lake such as increasing fish stocks of Tilapia (Orechromis spp.) but developed problems in Beris Lake when Toman (Channa micropeltes) was introduced to this lake which reduced the number of native fish species compared to previous studies. This study finds that different methods of fishery management and the introduction of alien species may affect the fisheries activities and fish diversity in those lakes.
\end{abstract}

Keywords: Beris reservoir, fisheries, habitat, lentic system, Muda lake, survey

\section{Introduction}

Freshwater habitats in Malaysia, which consist of both natural and man-made water bodies, are important source of aquatic resources. The habitats are highly varied, comprising of riverine, lacustrine (natural lakes, ox-bow lakes, reservoirs and ex-mining pools) and palustrine (freshwater and peat swamps and rice fields) habitats (WWFM, 2002). Besides, natural and artificial lakes are some examples of lacustrine habitats that refer to non-flowing or stagnant water bodies (Hoque et al., 1994; Yusoff et al., 1997; MOSTE, 1997; Le \& Facon, 2001). The 
impoundment of river alters the lotic system to lentic environment subsequently affect the hydrological regimes and biological conditions causing major changes in fish communities and other fauna structures. Even though the environment changes, most of the fish that inhabit reservoirs are riverine species as true lacustrine fish species are not available (Mohsin \& Ambak, 1983; Yusoff \& Gopinath, 1994; Zakaria-Ismail \& Lim, 1995; Li \& Xu, 1999). Currently there are 300 species of freshwater fishes in Malaysian inland water system documented in literature (Mohsin \& Ambak, 1983; Yusoff \& Gopinath, 2006). These aquatic resources including fish, however, are being threatened by human activities such as overexploitation of fish resources as well as pollution from land-based development (Yusoff \& Gopinath, 2006). Heavy fishing pressure which include fishing even small fish and lack of sustainable fishery management practices contributed to further decline of fish population.

Inland freshwater resources are also vulnerable to the non-indigenous species that can successfully outcompete them with the frequency, duration and magnitude of anthropogenic influences (Gherardi, 2007; Rahel, 2007; Francis, 2012). Non-indigenous species or alien species refer as a species, sub-species, race, variety or any lower taxon that might be exist, persist and then reproduce in the new environment which neither happens naturally in that particular geographical area nor ensue there before and its dispersion into that region was mediated directly or indirectly by human either purposely or unintentionally (Copp et al., 2005; Sultana \& Hashim, 2015). The introduction of non-indigenous species or alien species, such as in disused mining pond or floating cages, was part of fishery management practices to promote aquaculture development and create a potential solution for growing animal-protein deficiency (Yusoff et al. 2007; Rahim et al., 2013). Alien fish species was also introduced in Malaysia for the purpose of sport fishing (Rahim et al., 2013). However, the introduction of alien species was recognised as one factor that led to the increase rate of declination of global freshwater biodiversity (Sala et al., 2000). The presence of alien fish species was proved by Rahim (2012) which documented that aliens' species was not only found at ex-mining lake but also other artificial lakes and reservoirs in the middle and Southern parts of Peninsular Malaysia possibly introduced legally as part of aquaculture development or illegally by some reckless anglers. The existing and potential impacts of alien species were reported as alarming, making them priority for research, conservation and sustainable management (Vorosmarty et al., 2010).

The objective of this study was to ascertain the fishery practices specifically the commercial and recreational fishery activities in the Beris and Muda reservoirs and their relation to fish diversity in both lakes. Thus, this information will be useful for the Fisheries Department and other government agencies in monitoring the change in fish species population and composition before an appropriate action plan can be taken to conserve the freshwater resources.

\section{Method and study area}

\section{Study sites}

Two lakes were selected for this study namely Beris Lake and Muda Lake in Kedah, Malaysia (Figure 1). Muda Lake was created in 1969 under Muda Irrigation Scheme for the purpose of providing irrigation water to the Muda area that covering around 96,000 hectares to enable double cropping of rice per year (Muda Agricultural Development Authority - Lip, 2010). This lake area is about $15.5 \mathrm{~km}^{2}$ with catchment area around $984 \mathrm{~km}^{2}$. The operation and maintenance 
of this Muda Lake is under the supervision of Dam Management and Water Resources Division (Lip, 2010).

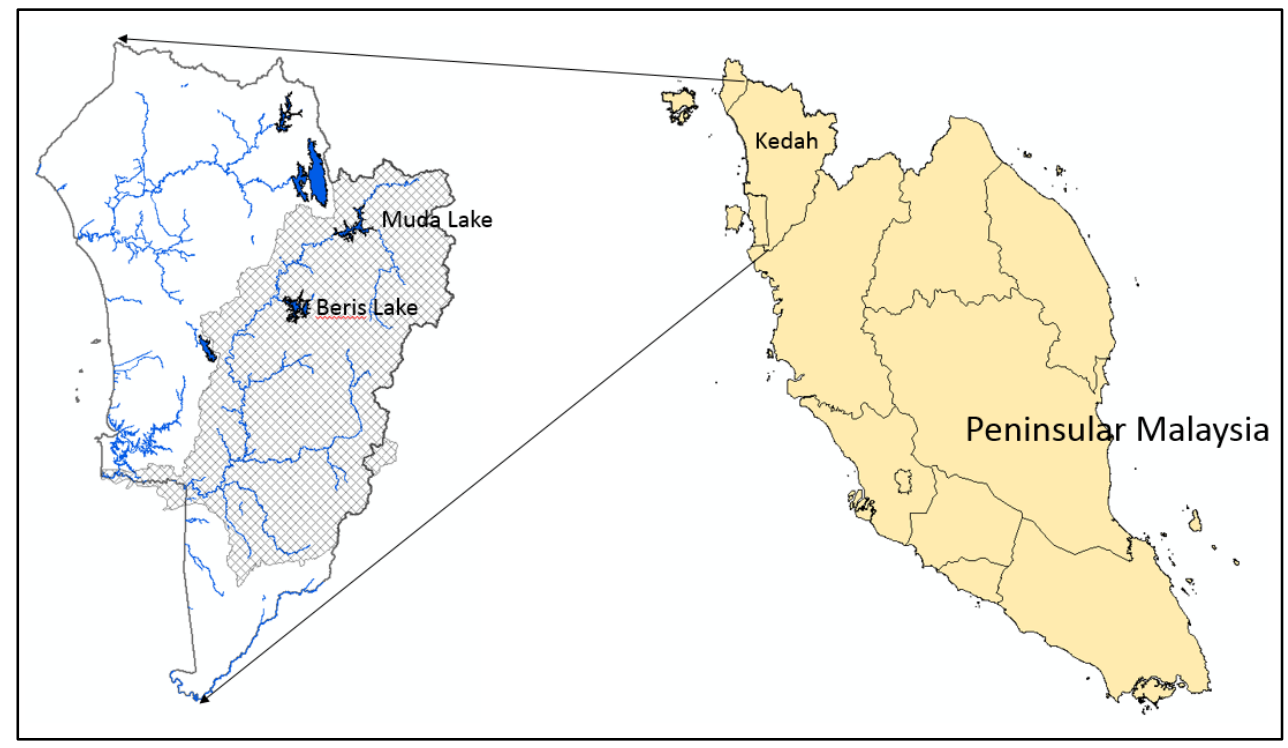

Figure 1. Location of study areas

Beris Lake was created in 2004 and located in a narrow valley of Sungai Beris. It stretching along $2.6 \mathrm{~km}$ upstream of confluence of Beris river and Muda River, Sik, Kedah (DID \& Universiti Malaysia Perlis, 2012). This lake is an artificial lake (Beris reservoir) used for regulating flows in Muda river basin to enhance water available for irrigation of paddy/upland crops, domestic and industrial water supply to Kedah and Penang. The lake has a total surface area of $13.7 \mathrm{~km}^{2}$ at normal level and $16.1 \mathrm{~km}^{2}$ at maximum level with catchment area around 116 $\mathrm{km}^{2}$ (DID \& Universiti Malaysia Perlis, 2012). The lake gross storage capacity is 122.4 million $\mathrm{m}^{3}$ with an effective storage of 144 million $\mathrm{m}^{3}$ (DID \& Universiti Malaysia Perlis, 2012).

\section{Data Collection}

This study was based on the survey and review of secondary data available in the published literature. The interview was carried out based on structured questionnaires (Lee et al., 2013) that focused on commercial and recreational fisheries. Survey interview was carried out in a semistructured manner between 10-15 September 2018 and 4-7 October 2018 using convenience sampling. The survey was held near the fish landing jetty or around the lake at locations where most locals gather, such as coffee shops and boat landing areas. A total of ten respondents were collected for each lake.

For the commercial questionnaire, target respondents were fishermen or any local people that were directly involved in fisheries activities. For recreational questionnaire, our respondents were mostly anglers that come for sport fishing. After the respondents completed their questionnaires, data was keyed in a binary matrix for further analysis. Independent t-test was used to test differences in fishery activities between the two lakes. All statistical analyses were performed using Excel. 


\section{Results and discussion}

\section{Fishing activities}

\section{a. Commercial fishing}

Based on our survey, there are about 50 fishermen in Muda Lake. This number has increased from 30 fishermen recorded in Lee et al. (2013) in 2012. About 80\% of the fishermen landed their fish during the morning period $(9.00$ to $11.00 \mathrm{am})$ while the balance landed in the afternoon ( 2.00 to $4.00 \mathrm{pm})$. The average catch per week was $100 \mathrm{~kg}$ with average income between RM50 to RM100 per day. The average net income per month was RM2865. All respondents in this study were male and considered as experience fishermen with more than 10 years of experience (Muda Lake). The fishermen in Beris Lake are considered young with 5 years of experience in average.

The differences in commercial fishing between Muda and Beris Lakes are shown in Table 1. One of the main differences were the nature of fishermen in both lake; Muda reservoir is manned by $100 \%$ full-time, licensed fishermen while Beris fishermen only work part-time $(p<0.05)$. Moreover, these two lakes also used different catch methods $(p<0.01)$. For example, Muda fishermen mostly used gill-nets as their tools for catching fish but Beris fisherman used rods and lines for their catch method.

Table 1. Comparison between Muda and Beris Lake on commercial fisheries activity

\begin{tabular}{lll}
\hline Lake & Muda $(\mathbf{N}=\mathbf{1 0})$ & Beris $(\mathbf{N}=\mathbf{1 0})$ \\
\hline Catch Method & Gill-nets $90 \%$ & Rod and line $90 \%$ \\
Purpose of fishing & For sell & For eat \\
Fisherman type & $100 \%$ fulltime & $100 \%$ partime \\
Location for fishing & Reservoir area and middle lake & Lakeside \\
Fishing transportation & Boat 100\% & Land transportation $(80 \%)$, boat $(20 \%)$ \\
Major fish catch & Tilapia and mixed fish & Mixed fish \\
\hline
\end{tabular}

Another difference found in this study was the purpose of fishing. Most Beris fisherman fished for personal consumption; however, all of the Muda fishermen catch the fish for sale (commercial gain). The locations for fishing are also different for the Muda and Beris fishermen. In Beris, most of them caught fish at the lakeside compared to Muda fishermen that fished at the reservoir area and the middle of the lake. This also affected their catch type; Muda fishermen caught tilapia and mixed fish as their major catch compared to Beris fishermen who only caught mixed fish.

The mode of transport for fishing activities was also different between these two lakes. Muda fishermen all used boats but only $30 \%$ of Beris fishermen use boats while the rest uses land transport. This difference is due to the fact that the Muda fishing area can only be accessed using water transport in contrast with Beris Lake which can be accessed by land transport such as cars or motorcycle. The most common fish that has been caught at Muda and Beris Lake are almost similar in species number. There are Tilapia, Sebarau, Catfish, snakehead, mixed fish also known as ikan Putih and a few other species. However, the number of fish caught are totally different for both lakes whereby Muda has a larger catch than Beris Lake. This is due to the fishing method of using many sizes of gill-net or certain locations for net setup. Furthermore, the different numbers of catch between these two lakes were also affected by different management 
methods. This is because Muda Lake is maintained by Fisheries Department with fish restocked every year for commercial fisheries' purposes. But in Beris Lake, the fisheries activity was limited to personal purposes and commercial fisheries are prohibited (no fish restocking conducted here).

\section{b. Recreational fishing}

The main difference between the two lakes in terms of recreational fishing was the targeted species (Table 2). In Muda, the main species that most anglers preferred to catch was Haruan (snakehead) followed by Baung and Sebarau $(p<0.05)$ for both seasons. However, in Beris the main target for fish catch is Toman and some anglers prefer to catch Sebarau. At Beris Lake, the only bait accepted for fishing in the lake are artificial bait. In contrast, anglers that fish at Muda Lake can use both live and artificial bait. The effect of using artificial bait in Beris lake cause the anglers to catch non-specific fish size (all sizes) compare to Muda which only records catch of grade $\mathrm{A}$ and $\mathrm{B}$ in size $(p<0.05)$. The practice of catch and release was also done by anglers at both lakes. Even though this method is popular, only anglers at Beris practice it for all fish sizes. The situation is quite different at Muda Lake where they only release small-sized fish and bring home the big-sized fish for eating or selling. Similar for both lakes, total fish that been caught are dependent on weather and location of fishing. Moreover, weight of fish and number of catches did not significantly differ between dry and wet season.

Table 2. Comparison between Muda and Beris Lake on recreational fisheries activity

\begin{tabular}{lll}
\hline Lake & Muda $(\mathbf{N}=\mathbf{1 0})$ & Beris $(\mathbf{N}=\mathbf{1 0})$ \\
\hline Species target & Haruan, baung, sebarau* & Toman, sebarau* \\
Baits used & Live bait 70\% & Artificial 100\% \\
Times spend for fishing & $20 \%,<5$ hours & $100 \%,>5$ hours \\
& $10 \%$, Overnight & \\
& $70 \%,>5$ hours & \\
Anglers expectation & Will come $\leq 1$ month & Will come $\leq 2$ month \\
Fish grade target & Grade A and B* & Non-specific* \\
Does catch and release done? & Yes, small size & Yes, all size \\
\hline
\end{tabular}

Our survey data showed that most of the anglers at Beris and Muda Lake are from Northern regions such as Kedah, Penang, Perak, Perlis and local people (from the nearby villages). However, the existence of many chalets providing boats for sport fishing makes Beris Lake more successful than Muda Lake. Figure 2 shows the percentage of angler's origins for both lakes.

At both lake, most of the anglers spend their time fishing for the targeted fish. From our survey data, most of them prefer to fish for more than 5 hours $(60 \%)$ followed by less than 5 hours, and very few inclined to spend overnight at this lake. Figure 3 showed the percentage of time anglers spend for fishing in Muda and Beris Lake. If compared between seasons, nearly half of angler's fish less than 5 hours in the wet season with lesser number of anglers in the dry season. The differences between seasons may be caused by evening rain which made conditions unsuitable for fishing. The selected places for fishing in Muda and Beris Lake for both seasons did not differ significantly. Our survey showed that anglers that visited both lakes return in the future within the period of one to two months. 


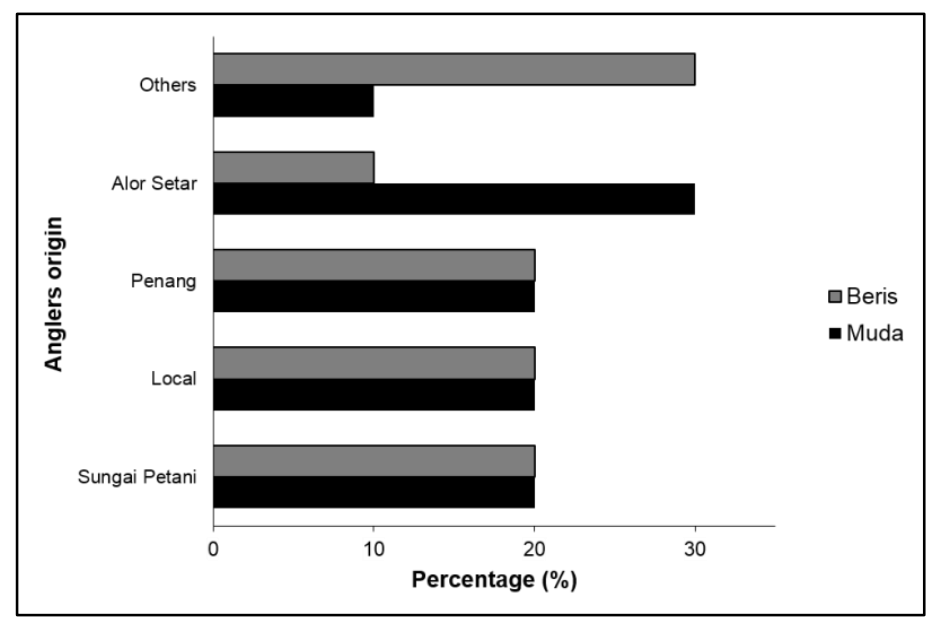

Figure 2. Percentage of angler origin at both Lake

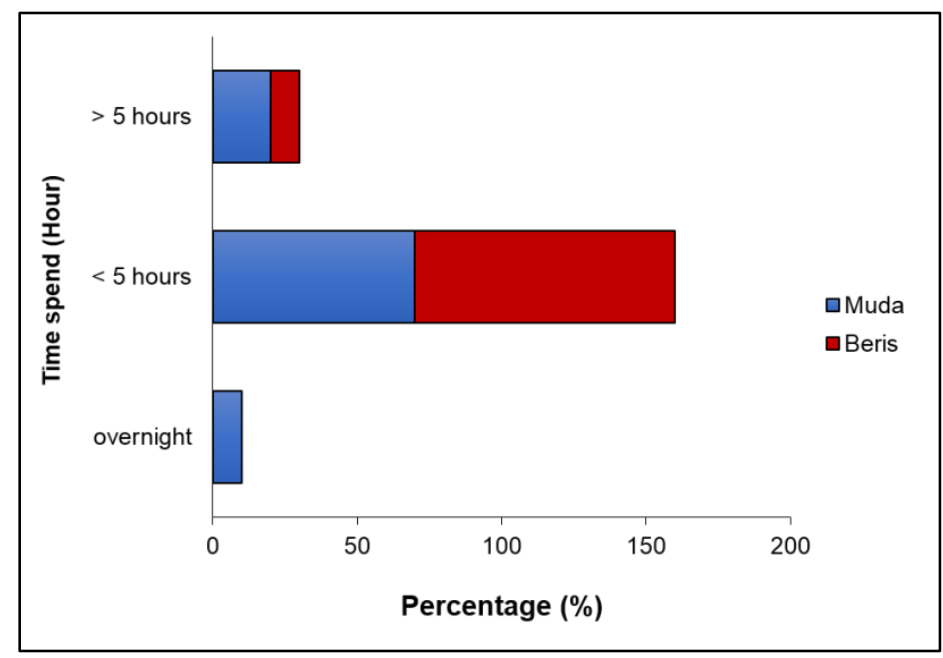

Figure 3. Percentage of anglers' time spend for fishing at both Lake

\section{Fish diversity}

Table 3 shows the list of fish species recorded in Beris and Muda lakes. The number of fish species that is found from our study was less than reported by Sah et al. (2016) and Zahari et al. (2000) for Beris Lake (our results for Muda Lake almost similar to Sah et al., 2012). Our study may have a smaller number of fish catch especially at Beris Lake because all data had been collected from anglers (using rod and lines) compared to Sah et al. (2016) that also included cast nets and gill-nets. Furthermore, the location and number of samplings are also factors that result in different numbers for both studies. The species number is similar with the species found in Ahning reservoir, Kedah (Sah et al., 2003). Both species numbers were much lower compared to the ones found in Chini and Bera Lake. Both Chini and Bera are natural lakes rich with wetland plants that encourage fish breeding. These natural lakes are not dammed with high structure, thus they received backflow of water from the main Pahang river during the monsoon seasons. This 
backflow possibly transports or encourages fishes to swim from the river into the lake hence increasing diversity.

A total of 16 fish species was recorded in our survey in Muda Lake. This number of fish species observed was less than reported by Sah et al. (2012) and Lee et al. (2013). The fish community in Muda Lake was dominated by cyprinid family consistent with earlier findings in Lee et al. (2013). Lee et al. (2013) recorded that cyprinids, comprising of 14 species, contributed $81 \%$ of fish caught in 2012 . Our survey reported that cyprinids and tilapia contributed $70 \%$ and $20 \%$ of fish caught respectively. According to the fishermen, the highest fish catch was observed in October to November (onset of wet monsoonal season) and lowest fish catch was experienced between December to February (rainy period) because of lesser fishing day by the fishermen due to raining day.

\section{Role of reservoir development and human activities}

After the impoundment, more species were observed to have decreased in Beris Lake compared to Muda Lake. The examples of fish species are Anabas testuneus, Trichgaster trichopterus (Pallas), Trichogaster pectoralis (Regan) and a few cyprinidae; these observations are almost similar to Ali's (1996) findings at Chenderoh reservoir. Some of the species mentioned above have disappeared because of biotic changes from river to reservoir. However, fish species at Bukit Merah Lake that are nearly endangered are Tor spp, arowana and possibly some cyprinidae. The different situations of Beris and Muda may be caused by different managements; Muda undergoes fish stocking every year, unlike Beris. Arowana was also stocked in Muda recently by the fishery department. This situation also may have caused the rapid reduction of Beris fish diversity and numbers.

According to Ali (1996), aquaculture activities were performed at the Chenderoh reservoir to support the local demand for freshwater fish. The same situation is noted in Beris reservoir whereby aquaculture activity was introduced to Beris Lake when catching fish from the natural environment is prohibited, as well as due to the declining fish numbers. This aquaculture activity can help to increase income from fisheries at Beris Lake. However, aquaculture activity may contribute to the deterioration of the lake environment.

Fisheries activity at Muda Lake is well maintained, although some fishermen reported a reduction in fish sizes in recent years. Most of the respondents surmised that the reduction in fish size may be caused by logging activities in the upstream areas of Muda River consistent with earlier findings (Lee et al., 2013). The same situation occurs in the Temenggor reservoir as has been mentioned by Hashim et al. (2012). Besides that, illegal fishing methods have also been used, which affected the fish catch in the upstream area of the reservoir; this reduced the total number of Kelah and some cyprinadae. According to Free et al. (2015), if this situation is not monitored extensively it can reduce fish stocks and also threaten the fish population. So, agencies such as the Fisheries Department need to be aware of the extent, fishermen's characters and motivations of illegal fishing to effectively develope and implement regulations. 
Table 3. Comparison of species caught from our study and other studies

\begin{tabular}{|c|c|c|c|c|c|c|c|c|}
\hline \multirow[t]{2}{*}{ Family } & \multirow[t]{2}{*}{ Species } & \multirow{2}{*}{$\begin{array}{l}\text { Local } \\
\text { name }\end{array}$} & \multirow[t]{2}{*}{ English name } & \multicolumn{3}{|c|}{ Muda } & \multicolumn{2}{|c|}{ Beris } \\
\hline & & & & $\begin{array}{l}\text { Our } \\
\text { study }\end{array}$ & $\begin{array}{l}\text { Lee et } \\
\text { al. } 2013\end{array}$ & $\begin{array}{l}\text { Sah et } \\
\text { al. } 2012\end{array}$ & $\begin{array}{l}\text { Our } \\
\text { study }\end{array}$ & $\begin{array}{l}\text { Sah et } \\
\text { al. } 2016\end{array}$ \\
\hline Ambassidae & $\begin{array}{l}\text { Parambassis } \\
\text { siamensis }\end{array}$ & Cermin & & - & + & - & - & - \\
\hline Bagridae & $\begin{array}{l}\text { Leiocassis } \\
\text { micropogon }\end{array}$ & $\begin{array}{l}\text { Baung } \\
\text { tikus }\end{array}$ & & - & - & + & + & + \\
\hline Bagridae & $\begin{array}{l}\text { Hemibagrus } \\
\text { nemurus }\end{array}$ & Baung & $\begin{array}{l}\text { Asian red tail } \\
\text { catfish }\end{array}$ & + & + & + & - & - \\
\hline Bagridae & $\begin{array}{l}\text { Hemibagrus } \\
\text { bleekeri }\end{array}$ & $\begin{array}{l}\text { Baung } \\
\text { biasa }\end{array}$ & & - & - & - & + & + \\
\hline Bagridae & Mystus castaneus & Baung & & - & + & + & - & - \\
\hline Bagridae & $\begin{array}{l}\text { Mystus } \\
\text { singaringan }\end{array}$ & Kenyeng & & - & + & - & - & - \\
\hline Belontidae & Betta pugnax & Sempilai & & - & - & + & - & - \\
\hline Chadidae & Ambassis kopsi & Cermin & & - & - & + & - & - \\
\hline Channidae & Channa lucius & Bujuk & & + & - & - & + & + \\
\hline Channidae & Channa gachua & Pecat & & - & - & + & - & - \\
\hline Channidae & Channa striata & Haruan & $\begin{array}{l}\text { Striped } \\
\text { snakehead }\end{array}$ & + & + & + & - & - \\
\hline Channidae & $\begin{array}{l}\text { Channa } \\
\text { micropeltes }\end{array}$ & Toman & & - & - & - & + & - \\
\hline Clariidae & Clarias batrachus & Keli kayu & $\begin{array}{l}\text { Phillipine } \\
\text { catfish }\end{array}$ & + & + & - & - & - \\
\hline Cichlidae & $\begin{array}{l}\text { Oreochromis } \\
\text { niloticus }\end{array}$ & $\begin{array}{l}\text { Tilapia } \\
\text { Hitam }\end{array}$ & Nile Tilapia & + & + & - & + & + \\
\hline Cobitidae & $\begin{array}{l}\text { Acantopsis } \\
\text { choirorhynchos }\end{array}$ & Pasir & & - & - & + & - & - \\
\hline Cobitidae & $\begin{array}{l}\text { Acantopsis } \\
\text { dialuzona }\end{array}$ & Pasir & & - & + & - & - & + \\
\hline Cyprinidae & $\begin{array}{l}\text { Anematichthys } \\
\text { apogon }\end{array}$ & Temperas & Beardless barb & - & + & - & - & - \\
\hline Cyprinidae & Barbodes altus* & & & - & - & - & - & + \\
\hline Cyprinidae & $\begin{array}{l}\text { Barbonymus } \\
\text { gonionotus* }\end{array}$ & $\begin{array}{l}\text { Lampan } \\
\text { Jawa }\end{array}$ & Silver barb & + & + & - & + & - \\
\hline Cyprinidae & $\begin{array}{l}\text { Barbodes } \\
\text { hexagonolepis }\end{array}$ & Tengas & & - & - & - & - & - \\
\hline Cyprinidae & $\begin{array}{l}\text { Barbonymus } \\
\text { schwanenfeldii }\end{array}$ & $\begin{array}{l}\text { Lampan } \\
\text { Sungai }\end{array}$ & $\begin{array}{l}\text { Tinfoil } \\
\text { barb/river carp }\end{array}$ & + & + & - & + & - \\
\hline Cyprinidae & $\begin{array}{l}\text { Crossocheilus } \\
\text { oblongus* }\end{array}$ & Susur batu & & - & - & + & - & + \\
\hline Cyprinidae & $\begin{array}{l}\text { Cyclocheilicthys } \\
\text { apogon* }\end{array}$ & Temperas & Carp & - & - & + & + & + \\
\hline Cyprinidae & Devario regina* & Danio & & - & - & + & - & + \\
\hline Cyprinidae & $\begin{array}{l}\text { Garra } \\
\text { combodogiensis }\end{array}$ & Susor batu & & - & - & + & - & - \\
\hline Cyprinidae & $\begin{array}{l}\text { Hampala } \\
\text { macrolepidota* }\end{array}$ & Sebarau & Hampala barb & + & + & + & + & + \\
\hline Cyprinidae & $\begin{array}{l}\text { Labiobarbus } \\
\text { leptocheilus }\end{array}$ & Kawan & & + & + & - & - & - \\
\hline Cyprinidae & Labiobarbus & Pucuk & Carp/barb & + & - & - & - & - \\
\hline
\end{tabular}


GEOGRAFIA Online ${ }^{\mathrm{TM}}$ Malaysian Journal of Society and Space 16 issue 1 (1-12)

(C) 2020, e-ISSN 2682-7727 https://doi.org/10.17576/geo-2020-1601-01

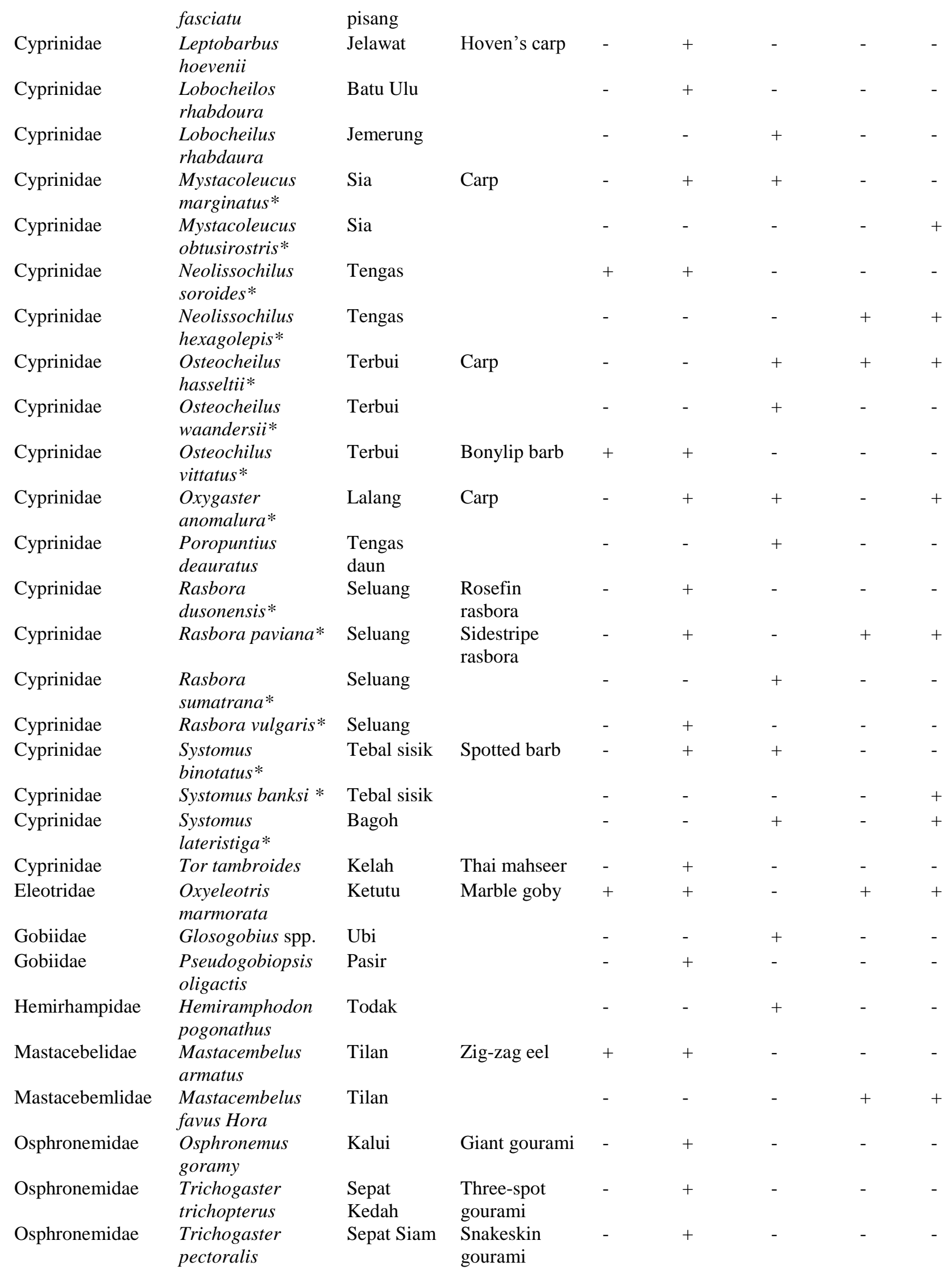


GEOGRAFIA Online ${ }^{\mathrm{TM}}$ Malaysian Journal of Society and Space 16 issue 1 (1-12)

(C) 2020, e-ISSN 2682-7727 https://doi.org/10.17576/geo-2020-1601-01

\begin{tabular}{|c|c|c|c|c|c|c|c|c|}
\hline Nandidae & $\begin{array}{l}\text { Pristolepis } \\
\text { fasciatus }\end{array}$ & Patung & & + & - & + & - & - \\
\hline Nandidae & Pristolepis grootii & Patung & & - & - & - & + & + \\
\hline Notopteridae & $\begin{array}{l}\text { Notopterus } \\
\text { notopterus }\end{array}$ & Selat & $\begin{array}{l}\text { Bronze } \\
\text { featherback }\end{array}$ & + & + & - & - & - \\
\hline Osreoglossidae & $\begin{array}{l}\text { Scleropages } \\
\text { formosus }\end{array}$ & $\begin{array}{l}\text { Kelisa/Aro } \\
\text { wana }\end{array}$ & $\begin{array}{l}\text { Asian } \\
\text { bonytongue }\end{array}$ & - & + & - & - & - \\
\hline Pangasiidae & $\begin{array}{l}\text { Pangasianodon } \\
\text { hypophthalmus }\end{array}$ & Patin & Striped catfish & - & + & - & - & - \\
\hline Pristolepididae & $\begin{array}{l}\text { Pristolepis } \\
\text { fasciata }\end{array}$ & Patung & $\begin{array}{l}\text { Malayan } \\
\text { leaffish }\end{array}$ & - & + & - & - & - \\
\hline Sisoridae & $\begin{array}{l}\text { Glyptothorax } \\
\text { major }\end{array}$ & Depu & & - & - & - & - & + \\
\hline
\end{tabular}

Note: + Species available, - Species not available, ${ }^{*}$ refer to ikan putih for small size

Alien species have also been introduced to Beris Lake and Muda Lake. One of the fish species that was introduced to both lakes is the Tilapia (Oreochromis spp). The reasons given for the introduction of tilapia for each lake was similar to the Sultana \& Hashim (2015) study, namely, to maintain the fish numbers and to resolve the decrease in fish catch. According to Lee et al. (2013) tilapia posed a threat to Muda lake due to its potential in altering native fish community composition. Besides that, alien species were also introduced to Beris Lake for purpose of sport fishing; these species include the Toman fish (Channa sp.; snakehead family). The introduction of Toman fish resulted in the increase in the number of anglers to Beris for sport fishing. However, the effect of introduction of this fish had been seen to reduce the small fish population around the lake. According to the Global Invasive Species Database (2018), this species is a voracious feeder of aquatic fauna especially the adults. Furthermore, if this species is left uncontrolled, it maybe affects other species and could permanently alter the stability of aquatic ecosystems. Three other alien species introduced in Muda Lake were Lampan Jawa, Sepat Siam and Patin (Lee et al., 2013). Continuous monitoring of fishery activities and fish diversity in these lakes are necessary for sustainable aquatic resource management. Further studies should be carried out to see the effect of human activity on water quality and planktons in relation to fish diversity in these two lakes.

\section{Conclusion}

The finding from our study concludes that both Beris Lake and Muda Lake are important manmade lakes for fisheries activity. However, the differences in fishery activities between these two lakes may be caused by different management methods of agencies, whereby Muda was set up for commercial fisheries and Beris for recreational fisheries. Besides that, the introduction of alien species, such as Tilapia (Orechromis sp.) and Toman (Channa sp.), may affect the fisheries activities and fish diversity in these lakes. Thus, continuous monitoring of the alien species in this new environment (lentic) should be performed to assess the long-term impact on the indigenous fish species. 


\section{Acknowledgments}

This work was funded by the Ministry of Water, Land and Natural Resources Malaysia under vote number P23170000190001.

\section{References}

Ali. A. (1996). Chenderoh Reservoir, Malaysia: The conservation and wise use of fish diversity in small flow-through tropical reservoir. Lakes and Reservoirs: Research and Management 2, 17-30.

Copp, G.H., Bianco, P.G., Bogutskaya, N.G., Eros, T., Falka, I., Ferreira, M.T., Fox, M.G., Freyhof, J., Gozlan, R. E., Grabowska, J., Kovac, V., Moreno-Amich, R., Naseka, A.M., Penaz, M., Povz, M., Przybylski, M., Robillard, M., Russell, I. C., Stakenas, S., Sumer, S., Vila-Gispert, A., \& Wiesner, C. (2005). To be, or not to be, a non-native freshwater fish? Journal of Applied Ichthyology, 21(4), 242-262.

DID, \& Universiti Malaysia Perlis. (2012). Tasik empangan Beris, Sik, Kedah. NAHRIM (Eds.), Managing lakes and their basins for sustainable use in Malaysia (Lake Briefs Report Series II). NAHRIM, Seri Kembangan.

Francis, R.A. (2012). Handbook of Global Freshwater Invasive Species. Earthscan, Oxon.

Free, C.M, Jensen, O.P., \& Mendsaikhan, B. (2015). A mixed-method approach for quantifying illegal fishing and its impact on an endangered fish species. PLOS ONE, 10(12), e0143960.

Gherardi, F. (2007). Understanding the impact of invasive crayfish. In. Gherardi, F. (Eds.), Biological invaders in inland waters: Profiles, distribution, and threats (pp 507-542). Invading Nature - Springer Series In Invasion Ecology, vol 2. Dordrecht, Springer.

Global Invasive Species Database. (2018). Species profile: Channa argus. Downloaded from http://www.iucngisd.org/gisd/species.php?sc=380 on 21-11-2018.

Hashim, Z.H., Shah, A.S.R.M., Mohammad, M.S., Mansor, M., \& Sah, S.A.M. (2012). Fishes of Sungai Enam and Sungai Telang in Temengor Reservoir, Perak, Malaysia. Check List, 8(1), 027-031.

Hoque, M.T., Yusoff, F.M., \& Mohsin, A.K.M. (1994). Freshwater ecosystems and fisheries in Malaysia: Environmental impacts and management strategies. pp. 44-47. Proceedings of Applied Biology Beyond the Year 2000. Third Symposium of Malaysian Society of Applied Biology. 1994 June 22-23rd.: Serdang, Selangor.

Le, H.T., \& Facon, T. (2001). From vision to action - A synthesis of experiences in Southeast Asia. The FAO-ESCAP Pilot Project on National Water Visions. FAO-ESCAP, Bangkok.

Lee, P.K.Y., Shah A.S.R.M., \& Khaironizam, M. Z. (2013). Assessment of the freshwater fisheries in Ulu Muda, Kedah. Petaling Jaya, Malaysia: WWF-Malaysia.

Li, S., \& Xu, S. (1999). Culture and capture of fish in Chinese Reservoirs. Penang. Southbound and the International Development Research Centre.

Lip, H. T. (2010) Tasik Pedu and Muda, Kedah, Lake Brief. In: Managing lakes and their basins for sustainable use in Malaysia (Lake Briefs Report Series 1) (pp. 125-37). Kuala Lumpur, Akademi Sains Malaysia.

Mohsin, A.K.M., \& Ambak, M.A. (1983). Freshwater fishes of Peninsular Malaysia. Serdang, Penerbit Universiti Pertanian. 
MOSTE. (1997). Assessment of biological diversity in Malaysia. Kuala Lumpur, Ministry of Science, Technology and the Environment.

Rahel, F. J. (2007). Biogeographic barriers, connectivity and homogenization of freshwater faunas: it's a small world after all. Freshwater Biology, 52(4), 696-710.

Rahim, K.A.A. (2012). Diversity, ecology, and distribution of non-indigenous freshwater fish in Malaysia (PhD Dissertation). Retrieved from Universiti Putra Malaysia.

Rahim K.A.A., Esa, Y., \& Arshad A., (2013). The influence of alien fish species on native fish community structure in Malaysian waters. Kuroshio Science, 7(1), 81-93.

Sala, O.E., Chapin, F.S., Armesto, J.J., Berlow, E., Bloomfield, J., Dirzo, R., Huber-Sanwald, E., Huenneke, L.F., Jackson, R.B., Kinzig, A., Leemans, R., Lodge, D.M., Mooney, H.A., Oesterheld, M., Poff, N.L., Sykes, M.T., Walker, B.H., Walker, M., \& Wall, D.H. (2000). Global biodiversity scenarios for the year 2100. Science, 287(5459), 1770-1774. DOI: 10.1126/science.287.5459.1770

Sah, A.S.R.M., \& Ali, A. (2003). Fish community of Ahning Reservoir: Its biodiversity and productivity. In. Othman, A.S., \& Ali, A.B. (Eds.), Biodiversity Resources of Lake Ahning. Pulau Pinang, Universiti Sains Malaysia.

Sah, A.S.R.M., Putih, K., \& Othman, A.S. (2016). A preliminary study of fishes of Beris reservoir, Kedah, Malaysia. Malayan Nature Journal, 68(3), 73-81.

Sah, A.S.R.M., Samat, A., Putih, K., \& Mansor, K.N.A. (2012). Notes on the freshwater fishes at selected headwater streams of the Ulu Muda Forest Reserve, Kedah Darul Aman. Malayan Nature Journal, 64(3), 147-152.

Sultana, M., \& Hashim, Z.H. (2015). Invasive alien fish species in freshwater of the continents. Journal of Environmental Science \& Natural Resources, 8(2), 63-74.

Vorosmarty, C.J., McIntyre, P.B., Gessner, M.O., Dudgeon, D., Prusevich, A., Green, P., \& Davies, P.M. (2010). Global threats to human water security and river biodiversity. Nature, 467(7315), 555-561.

WWFM. (2002). Strategy framework for conservation and management of indigenous freshwater fish in Peninsular Malaysia. World Wide Fund for Nature (WWF) Malaysia's Internal Document. Kuala Lumpur, WWF Malaysia.

Yusoff, F.M., \& Gopinath, N. (1994). The status of inland fisheries in Malaysia. Rome: FAO fisheries Report No. 512 Supplement, pp. 225-239.

Yusoff, F.M., Subasinghe, R.P., \& Zaki, M.S.M., (1997). Fisheries and aquatic environmental education in Malaysia In. Japar, S.B., Yusoff, F.M., Zaki, M.S.M., \& Petr T. (Eds.), Fisheries and the Environment: Beyond 2000. (pp. 81-88). Serdang, Universiti Putra Malaysia.

Zahari, A., Misri, S., \& Ramley A.B. (2000). The fish fauna of Sungai Beris (Preimpoundment survey of the Beris Reservoir). Retrieved from http://www.fri.gov.my/ pppat/bris/brisriver.pdf

Zakaria-Ismail, M., \& Lim, K.K.P. (1995). The fish fauna of Tasik Temenggor and its tributaries south of Banding, Hulu Perak, Malaysia. Malayan Nature Journal, 48(3-4), 319-332. 